\title{
Yesterday's heroic measure is now standard procedure: Extracorporeal membrane oxygenation as a bridge to lung transplant
}

\author{
Victor van Berkel, $\mathrm{MD}, \mathrm{PhD}$ \\ From the Department of Cardiovascular and Thoracic Surgery, University of Louisville School of Medicine, \\ Louisville, Ky. \\ Disclosures: Author has nothing to disclose with regard to commercial support. \\ Received for publication Oct 16, 2017; accepted for publication Oct 25, 2017; available ahead of print Nov 29, \\ 2017. \\ Address for reprints: Victor van Berkel, MD, $\mathrm{PhD}$, Department of Cardiovascular and Thoracic Surgery, Univer- \\ sity of Louisville School of Medicine, 201 Abraham Flexner Way, Ste 1200, Louisville, KY 40202 (E-mail: \\ victor.vanberkel@louisville.edu). \\ J Thorac Cardiovasc Surg 2018;155:1314-5 \\ $0022-5223 / \$ 36.00$ \\ Copyright $($ C 2017 by The American Association for Thoracic Surgery \\ https://doi.org/10.1016/j.jtcvs.2017.10.106
}

Extracorporeal membrane oxygenation (ECMO) is a complex technique that allows for respiratory and/or cardiac support in critically ill patients. There are many indications for the implementation of ECMO, including adult respiratory distress syndrome, inability to wean from bypass postcardiotomy, and cardiogenic shock. It can be used both in a veno-venous circuit for pure pulmonary support, as well as in a veno-arterial circuit for concomitant cardiac support. Because of the technical expertise required, and considerable financial costs, the use of ECMO has been limited to patients with high risk of mortality and whose underlying disease process is reversible, or as a short-term bridge to definitive therapy.

Hill and colleagues ${ }^{1}$ first reported the use of ECMO as a treatment for the management of cardiopulmonary failure in 1972. Outcomes in adult populations were generally dismal, and a randomized prospective trial in 1979 demonstrated no survival benefit of ECMO for patients with acute respiratory failure. ${ }^{2}$ For the next 2 decades, use of ECMO in adult populations was sporadic and limited to a few centers. However, significant improvements in ECMO-associated technologies (specifically membrane oxygenators and centrifugal pumps) have led to a recent resurgence of the technology. ECMO gained special attention during the 2009 H1N1 influenza outbreak, with ECMO successfully being used to manage a significant proportion of patients with severe respiratory failure. ${ }^{3}$ The Efficacy and Economic Assessment of Conventional Ventilatory Support versus Extracorporeal Membrane Oxygenation for Severe Adult Respiratory Failure trial in the United Kingdom demonstrated a survival benefit for patients transferred to ECMO-capable centers, ${ }^{4}$ further suggesting the increased effectiveness of modern ECMO circuits.

During the past several years, there has been a resumed push at individual centers to use ECMO as a bridge to

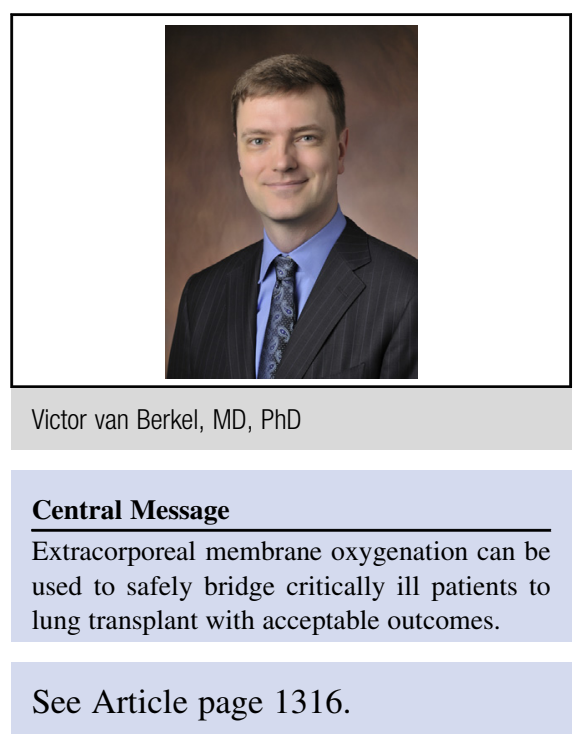

lung transplant. Although several trials have evaluated the outcomes of ECMO in respiratory failure, very few have examined the utility of ECMO as a bridge to transplant. The existing literature is limited to several single-center retrospective studies, the results of which vary widely. ${ }^{5-7}$ In this issue, Hoetzenecker and colleagues ${ }^{8}$ report the largest single-center collection to date of bridged patients, examining their experience over a 10 -year period. They report use of a variety of techniques for support and describe how their experience has changed over time. Although they demonstrate reasonable short-term and long-term survival for patients with cystic fibrosis and interstitial lung disease, they notably found a marked decrease in survival for patients with primary pulmonary hypertension, as well as for patients undergoing retransplant.

Although multiple centers have published articles describing their successes with transplanting patients following the use of veno-venous ECMO, there are no universally accepted indications for this practice. ${ }^{5,6,9}$ Most studies recommend the use of ECMO primarily in younger patients who experience acute decompensation in a chronic pulmonary process. ${ }^{10,11}$ Although Hoetzenecker and colleagues ${ }^{8}$ suggest caution regarding the use of ECMO in the case of retransplant, or in patients with severe pulmonary hypertension, they also reinforce the growing enthusiasm for the use of this technology to bridge critically ill patients to transplant. 


\section{References}

1. Hill JD, O’Brien TG, Murray JJ, Dontigny L, Bramson ML, Osborn JJ, et al. Prolonged extracorporeal oxygenation for acute post-traumatic respiratory failure (shock-lung syndrome). Use of the Bramson membrane lung. N Engl J Med. 1972:286:629-34.

2. Zapol WM, Snider MT, Hill JD, Fallat RJ, Bartlett RH, Edmunds LH, et al. Extracorporeal membrane oxygenation in severe acute respiratory failure. A randomized prospective study. JAMA. 1979;242:2193-6.

3. Noah MA, Peek GJ, Finney SJ, Griffiths MJ, Harrison DA, Grieve R, et al. Referral to an extracorporeal membrane oxygenation center and mortality among patients with severe 2009 influenza A(H1N1). JAMA. 2011;306:1659-68.

4. Peek GJ, Mugford M, Tiruvoipati R, Wilson A, Allen E, Thalanany MM, et al. Efficacy and economic assessment of conventional ventilatory support versus extracorporeal membrane oxygenation for severe adult respiratory failure (CESAR): a multicentre randomised controlled trial. Lancet. 2009;374: 1351-63.

5. Lafarge M, Mordant P, Thabut G, Brouchet L, Falcoz PE, Haloun A, et al. Experience of extracorporeal membrane oxygenation as a bridge to lung transplantation in France. J Heart Lung Transplant. 2013;32:905-13.

6. Bittner HB, Lehmann S, Rastan A, Garbade J, Binner C, Mohr FW, et al Outcome of extracorporeal membrane oxygenation as a bridge to lung transplantation and graft recovery. Ann Thorac Surg. 2012;94:942-9.

7. Hoopes CW, Kukreja J, Golden J, Davenport DL, Diaz-Guzman E, Zwischenberger JB. Extracorporeal membrane oxygenation as a bridge to pulmonary transplantation. J Thorac Cardiovasc Surg. 2013;145:862-7.

8. Hoetzenecker K, Donahoe L, Yeung JC, Azad S, Fan E, Ferguson ND, et al. Extracorporeal life support as a bridge to lung transplant: experience of a highvolume transplant center. J Thorac Cardiovasc Surg. 2018;155:1316-28.

9. Lang G, Taghavi S, Aigner C, Rényi-Vámos F, Jaksch P, Augustin V, et al. Primary lung transplantation after bridge with extracorporeal membrane oxygenation: a plea for a shift in our paradigms for indications. Transplantation. 2012 93:729-36.

10. Bermudez CA, Rocha RV, Zaldonis D, Bhama JK, Crespo MM, Shigemura N, et al. Extracorporeal membrane oxygenation as a bridge to lung transplant: midterm outcomes. Ann Thorac Surg. 2011;92:1226-31.

11. Toyoda Y, Bhama JK, Shigemura N, Zaldonis D, Pilewski J, Crespo M, et al. Ef ficacy of extracorporeal membrane oxygenation as a bridge to lung transplantation. J Thorac Cardiovasc Surg. 2013;145:1065-70. 